\title{
Male circumcision and global HIV/AIDS epidemic challenges
}

\author{
Emiola Oluwabunmi Olapade-Olaopa, Mudasiru Adebayo Salami and Taiwo Akeem Lawal*i(
}

\begin{abstract}
Background: Given the devastating mortality and morbidity associated with HIV/AIDS, many potential prevention measures against HIV infection continue to be explored. Most prevention methods are in the realm of sexual behavior change. However, of all aspects of human behavior, it is sexual behavior that is least amenable to change. Newer and simpler interventions are therefore required. Male circumcision, the surgical removal of some or all of the foreskin (or prepuce) from the penis, is one of the ways being promoted as a preventive measure. This paper reviews the scientific basis and evidence for the efficacy of male circumcision within the context of the global challenges involved.

Main body: We reviewed articles with emphasis on male circumcision and HIV/AIDS transmission. Published abstracts of presentations at international scientific meetings were also reviewed.

Conclusions: Current epidemiological evidence supports the promotion of male circumcision for HIV prevention, especially in populations with high HIV prevalence and low circumcision rates. Three notable randomized control trials strengthen the case for applied research studies to demonstrate that safe male circumcision is protective at the population level, particularly as ideal and well-resourced conditions of a randomized trial are often not replicated in other service delivery settings. Ethically and culturally responsive strategies in promoting circumcision in a culturally heterogenous world need to be developed, too. Male circumcision should also be viewed as a complementary measure along with other proven approaches to turn the HIV/AIDS epidemic around.
\end{abstract}

Keywords: Circumcision, HIV/AIDS, Global surgery, Prevention

\section{Background}

The global HIV/AIDS epidemic continues to grow despite global efforts aimed at stemming the tide. The UNAIDS 2016 AIDS epidemic update reported an estimated 36.7 million (34.0-39.8 million) people as living with HIV [1]. This figure includes an estimated 2.1 million (1.8-2.4 million) adults and children who were newly infected with HIV in 2015. Given the devastating mortality and morbidity associated with HIV/AIDS, many intervention methods, preventive or therapeutic, are currently in use, while new ones are being developed. Proven prevention methods include abstinence, mutual monogamy, reducing number of sex partners, and correct and consistent condom use. Other available interventions

*Correspondence: takeemlawal@gmail.com

Department of Surgery, College of Medicine, University of Ibadan and University College Hospital, PMB 5017, Ibadan 200212, Nigeria are highly active antiretroviral therapy (HAART), shortcourse antiretroviral therapies and cesarean section in preventing mother-to-child transmission, post-exposure prophylaxis, and treatment of sexually transmitted infections (STIs) [2]. Most prevention methods are in the realm of sexual behavior change. However, of all aspects of human behavior, it is sexual behavior that is least amenable to change [3]. Newer and simpler interventions are therefore required. In spite of sub-Saharan Africa recording a rise in the population of people living with HIV from 23.5 million in 2010 to 25.5 million in 2015, there was a decline in the rate of new infections from 1.6 million in 2010 to 1.4 million in 2015 [1]. Although access to HAART has doubled over the period, the reduction in new infections per year has been partly attributed to the rollout of large-scale voluntary male medical circumcision (VMMC) [4-7]. In fact, over the period, sub-Saharan Africa recorded the largest proportionate decline 
in new HIV infections. Male circumcision, the surgical removal of some or all of the foreskin (or prepuce) from the penis [8], is one of the ways being promoted as a preventive measure. This paper reviews the scientific basis and evidence for the efficacy of male circumcision within the context of the global challenges involved.

\section{Main text}

\subsection{Scientific rationale}

The foreskin is richly supplied with Langerhans and dendritic cells (target cells for HIV infection), and the inner foreskin epithelium is thin and poorly keratinized compared to the dry external skin surface $[9,10]$. The foreskin is also more susceptible to HIV infection in laboratory studies [11]. In contrast, the glans penis has a highly keratinized epithelium to protect it from trauma during intercourse. Thus, unless gross lesions are present, the glans is a most unlikely site for HIV entry, unlike the foreskin that may be a route of entry of pathogens once injured [12] as well as provide a conducive environment for viral survival $[8,12]$. Indirect factors may be a reduction in acquisition of other STIs, which in turn will reduce the acquisition of HIV. In particular, the higher rates of sexually transmitted genital ulcerative disease, such as syphilis, observed in uncircumcised men may also increase susceptibility to HIV infection [13]. More recently, the interplay of the mucosal environment, fibroblasts and dendritic cells and the loss of mucosal integrity has been suggested as a possible mechanism for HIV invasion [14].

\section{The evidence}

\subsection{Observational studies and reviews}

The first paper suggesting a protective effect of male circumcision against HIV infection was published in 1986 [15]. Since then, other cross-sectional, prospective, and ecologic (population-level) studies have identified lack of male circumcision as a risk factor for HIV infection. Some of these observational studies have observed that most men living in East and Southern Africa, the regions with the highest prevalence of HIV, are not circumcised [16-18]. The majority of these observational studies were cross-sectional, while a minority was prospective [19-24]. In a systematic review and meta-analysis of 27 reports from different countries in sub-Saharan Africa, Weiss et al. [25] showed that male circumcision appeared to reduce the relative risk of HIV infection to 0.56. Also, among high-risk groups, such as STD clinic attendees, the relative risk was reduced to 0.29 . In a prospective study of HIV-discordant couples in Uganda where the woman was HIV positive, there was no seroconversion in 50 circumcised men compared to 40 seroconversions in 137 uncircumcised men over a 30 -month period, a highly significant difference $(p=0.004)$ [26]. Similar findings were reported from another study conducted in Uganda, controlling for viral load was significant, in addition to the circumcision status, in reduction of transmission rate in heterosexual and discordant couples [20]. This has been attributed to decreased viral shedding from circumcised men or reduction in ulcerative STIs acquired by female partners of circumcised men [27]. A Cochrane review that included stringent assessment of 10 potential confounding factors and was stratified by study type or study population was published in 2003 [28]. The review concluded that there was a strong association between male circumcision and prevention of HIV, especially among high-risk groups.

Ecologic studies have also shown a strong relationship between circumcision status and HIV transmission. Countries in the Afro-Asian region with low circumcision rates have a much higher prevalence of HIV infection when compared to countries with much higher circumcision rates $[3,29,30]$. Contrary reports include that of Garenne who observed that natural experiments in other settings like Tanzania and Cote d'Ivoire do not support the protective effects of circumcision [31]. He submitted that in Tanzania with multiple ethnic groups where circumcision status differs between groups that lived in urban and rural settings, there were no statistically significant differences between HIV prevalence among largely circumcised or largely uncircumcised ethnic groups. In addition, the argument that the large epidemic in Abidjan, Cote d'Ivoire, and surrounding areas in the late 1980s was largely due to the lack of male circumcision of the local ethnic groups is not supported by the rapid increase in HIV infection among migrant workers from Burkina Faso and Mali living in Abidjan, who were circumcised. Partial explanations for these inconsistencies may perhaps be offered by recent work by Talbott using cross-country regression data from 77 countries. He argued that rather than the male circumcision being the key to slowing the AIDS epidemic, it is the number of infected prostitutes that is highly significant and robust in explaining HIV prevalence levels across countries [32].

\subsection{Clinical trials}

To date three randomized, controlled clinical trials have provided firm evidence that adult male circumcision halves the risk of acquiring HIV. The study conducted in South Africa [33] was stopped in 2005 and those in Kenya [34] and Uganda [35] were stopped in 2006 after their interim analyses found that medical circumcision reduced male participants' risk of HIV infection. In these studies, men who had been randomly assigned to the circumcision group had a 60\% (South Africa), 53\% (Kenya), and $51 \%$ (Uganda) lower incidence of HIV infection 


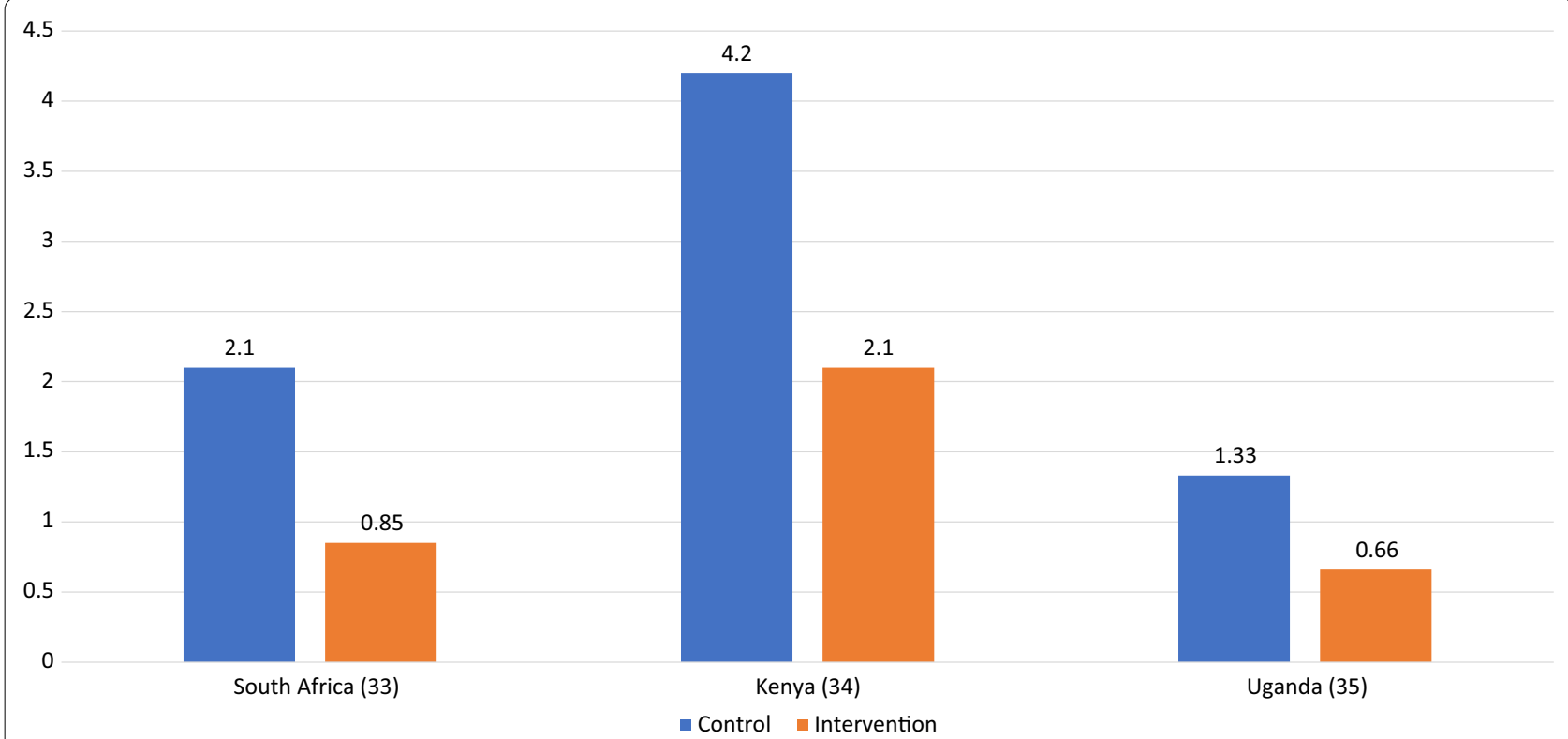

Fig. 1 Comparison of the cumulative HIV incidence (percentage in Kenya and cases per 100 person years in South Africa and Uganda) between control (delayed circumcision) and intervention (immediate circumcision) groups in the three randomized control trials

compared to men assigned to the wait list group to be circumcised at the end of the study (Fig. 1).

Methodological arguments against these studies include sampling bias implicit in the South African study in using a pool of men who wanted to be circumcised leading to a possible self-selection [36]. Equally important is the trial to assess the impact of male circumcision on the risk of HIV transmission to female partners from HIV-infected men, led by researchers at John Hopkins University, which reported that there was no significant difference in HIV acquisition rate from HIV-infected male spouses irrespective of circumcising the partners at inclusion into the study or not [37]. That study, which was conducted in Rakai, Uganda, had to be aborted early because of its futility [37]. Further studies have demonstrated that while circumcision reduces the acquisition of STIs such as high-risk human papilloma virus infections by spouses of HIV negative men, the same benefit could not be replicated in studies conducted among HIVinfected men and their partners [38, 39]. Furthermore, longitudinal evidence of the range of health benefits that male circumcision provides [40], modeling based on rollouts or expansion of VMMC [41-43], and cost-effectiveness data in both North America [44] and Africa [4, 5, 41, $42,45,46]$ provide further evidence to support the health benefits of male circumcision.

\section{HIV/AIDS epidemiology and male circumcision}

Although the modes of HIV transmission varies in different parts of the world, male circumcision still appears to be beneficial beyond heterosexual transmission pattern. Kreiss and Hopkins [47] and Buchbinder et al. [48] in different cross-sectional studies reported a twofold increased risk of HIV prevalence or seroconversion among males having sex with males (MSM) associated with non-circumcision. This could be due to practice of mutual masturbation among MSM during which the infected ejaculate of one partner can come into contact with the other's penis [3]. Some gay men also practice "docking", where one man's penis is inserted inside the foreskin of his partner, followed by mutual masturbation [3]. The published literature on this subject to date has differed from one continent to the other since most researches in Africa had focused on heterosexual transmission, while the major mode of transmission of HIV in the USA remains penile-anal intercourse in homosexual partners $[49,50]$. Although one prospective cohort study of HIV-seronegative men found a doubling in the risk of HIV acquisition among uncircumcised men [48], the population-attributable fraction for this risk factor was only $10 \%$. Also unknown is whether the effect of male circumcision differs by HIV-1 subtype (predominately subtype B in the USA and subtypes A, C, and D in Africa). This argument clearly applies to other parts of the world beyond Africa and indicates the need for further studies. 


\subsection{Socioreligious factors in circumcision}

About two-thirds to three quarters of the world's males are uncircumcised, and there are substantial differences in circumcision rates and timing in different parts of the world $[7,51]$. The prevalence of neonatal circumcision is influenced by religious affiliation, country of origin, ethnicity, residential area, maternal education, socioeconomic status, the type of health insurance, and the attitudes of parents and physicians [52-54]. Male circumcision is carried out around puberty in some cultures as a preparation for manhood [3, 55-58]. Acceptability problems may clearly arise when introduced into areas where it is not yet popular. Westercamp and Bailey [59] reviewed 13 acceptability studies done in subSaharan Africa among non-circumcising communities and reported two-thirds of men favoring the procedure. Nearly $70 \%$ of women from the review would prefer their partners to be circumcised. Furthermore, $81 \%$ of both men and women were willing to circumcise their male children. Price, pain, and complications were universal concerns that need to be addressed in a rollout of male circumcision. There is a need to ensure that the procedure is affordable to those who need it, that pain is minimized through proper anesthesia, and that complications are limited by proper training, procedure, and oversight during implementation [60]. It is also noteworthy that $80 \%$ of eligible control participants in the Ugandan trial had agreed to be circumcised by the time the study was closed [35]. However, acceptability studies are still required in other parts of the world with a high burden of HIV, such as Southeast Asia, before implementation of such a program in these countries.

Related to the above are ethical issues regarding mass circumcision. Some authors have pointed to a need to address the ethics of compromising a child's bodily integrity for an issue that might not affect him for many years to come [60]. Or put in another way; is it ethical to circumcise infants and young children who cannot consent to the procedure? And is it ethical to circumcise everybody, even if many will not benefit from the intervention-for example people who do not engage in risky sexual behavior or are HIV positive [61]? The answers to these questions will vary depending on the local, cultural, and religious practices and the reality of epidemiology of HIV/AIDS in each locality. As put forward by Benatar, a moral judgment has to be made considering local conditions [62].

\subsection{The procedure and its complications}

Circumcision procedures vary, depending on the person operating and facilities available. Probably the simplest, safest, and least painful method of male circumcision is to use the disposable PlastiBell device [3]. The technique is currently being promoted throughout Bostwana, a country where male circumcision was previously universally practiced, but was abandoned during colonial rule [63]. Currently, Botswana has one of the highest rates of HIV infection in the world [3]. More recently, with largescale VMMC rollouts in Eastern and Southern Africa, and the more challenging technical requirements for the procedure, hemostasis and wound healing in adults, the use of devices to accomplish the procedure, safely, have become necessary. Such include in situ devices (Shang Ring and PrePex) and circular disposable devices [64-69].

The reported complication rates vary widely, depending on the type of study (survey vs. chart review vs. prospective), the age at which the procedure is done, the setting (medical facility vs. community), the person operating (physician vs. traditional practitioner), the type of instrument used, the level of sterility under which the surgery is done, the definitions of specific complications, and length of follow-up. In large studies of infant circumcision in the USA, complications rates range from 0.2 to $2.0 \%[2,8,70]$. The complication rate may be higher in adults and among those performed in traditional or nonmedical settings [2, 71]. Generally, the most common complications are pain, hemorrhage, infection, meatal stenosis, frenular ulcer, buried (trapped) penis, preputial adhesions, and incomplete or inadequate circumcision $[8,72]$. It has therefore been suggested that circumcisions be practiced by those with basic surgical training on wound closure and maintenance of hemostasis [25, 33-35]. Neonatal circumcision is procedurally less challenging, has fewer complications, and is cheaper than circumcision in adulthood [40, 44]. However, if male circumcision is applied only to neonates, it will take at least a generation before a population-level effect, on HIV prevention, etc., occurs [60].

The effect of male circumcision on sexuality remains controversial [73-79]. Two studies clearly illustrate the controversy [77, 79]. Sorells et al. studied adult male volunteers with no history of penile pathology or diabetes with a Semmes-Weinstein monofilament touch-test to map the fine-touch pressure thresholds of the penis [79]. They reported that circumcision is associated with the reduction in fine-touch sensation on the glans penis.

Circumcision, they submitted, ablates the most sensitive parts of the penis. However, Payne et al. [77] studying penile sensation in sexually aroused subjects, and how arousal affects sensation found no differences in genital sensitivity between the uncircumcised and circumcised groups. Both studies perhaps illustrate the fact that structure may not always completely explain function.

\subsection{Counseling and education challenges}

Along with the excitement attending the finding of male circumcision as a permanent preventive intervention that 
can reduce the risk of HIV infection, the fact that it does not provide $100 \%$ protection should always be kept in focus. The challenge will be to learn how to convey the public-health message that, although circumcision reduces the risk of HIV, it is nevertheless necessary to advocate the use of condoms, because circumcised individuals are still at risk of infection $[56,61,80]$.

\section{Conclusions}

Current epidemiological evidence clearly supports the promotion of male circumcision for HIV prevention, especially in populations with a high HIV prevalence and low circumcision rates.

It is, however, important to dispel any belief of circumcision being as effective when applied in isolation of other behavioral changes or indeed as the complete answer to HIV prevention. Indeed the possibility of turning round the epidemic depends on the use of all known proven approaches in a consistent and focused manner. These approaches include HIV testing and counseling, diagnosis and treatment of STIs, promotion of condom usage, and behavioral change counseling toward promotion of abstinence and mutual monogamy, and the use of possible future-proven new methods like microbicides.

\begin{abstract}
Abbreviations
AIDS: Acquired Immune Deficiency Syndrome; HAART: highly active antiretroviral therapy; HIV: human immunodeficiency virus; MSM: males having sex with males; UNAIDS: United Nations Programme on HIV and AIDS; STD: sexually transmitted disease; STI: sexually transmitted infection; VMMC: voluntary male medical circumcision.
\end{abstract}

\section{Acknowledgements}

None.

\section{Authors' contributions}

EOO conceptualized the study, provided support data for the review, and revised the initial draft critically for intellectual content; MAS and TAL contributed to the study concept and design of the review, and wrote the draft. All authors read and approved the final manuscript.

\section{Funding}

No external funding was received for this project.

\section{Availability of data and materials}

The materials used for the review are available from the corresponding author on reasonable request.

\section{Competing interests}

The authors declare that they have no competing interests.

\section{Consent for publication \\ Not applicable.}

Ethics approval and consent to participate

Not applicable.

Received: 21 October 2019 Accepted: 29 October 2019

Published online: 18 November 2019
References

1. UNAIDS GA (2016) Update 2016. Geneva, Switzerland. http://www. unaids.org/en/resources/documents/2016/Global-AIDS-update-2016. Accessed 28 Juny 2017

2. Muula AS (2006) The complications and safety of male circumcision: implications for HIV prevention. Int Urol Nephrol 38:293

3. Short RV (2006) New ways of preventing HIV infection: thinking simply, simply thinking. Philos Trans R Soc Lond B Biol Sci 361:811-820

4. Awad SF, Sgaier SK, Ncube G, Xaba S, Mugurungi OM, Mhangara MM et al (2015) A reevaluation of the voluntary medical male circumcision scaleup plan in Zimbabwe. PLoS ONE 10:e0140818

5. Awad SF, Sgaier SK, Tambatamba BC, Mohamoud YA, Lau FK, Reed JB et al (2015) Investigating voluntary medical male circumcision program efficiency gains through subpopulation prioritization: insights from application to Zambia. PLoS ONE 10:e0145729

6. Binagwaho A, Pegurri E, Muita J, Bertozzi S (2010) Male circumcision at different ages in Rwanda: a cost-effectiveness study. PLoS Med 7:e1000211

7. Lawal TA, Olapade-Olaopa EO (2017) Circumcision and its effects in Africa Transl Androl Urol 6:149-157

8. Alanis MC, Lucidi RS (2004) Neonatal circumcision: a review of the world's oldest and most controversial operation. Obstet Gynecol Surv 59:379-395

9. Donoval BA, Landay AL, Moses S, Agot K, Ndinya-Achola JO, Nyagaya EA et al (2006) HIV-1 target cells in foreskins of African men with varying histories of sexually transmitted infections. Am J Clin Pathol 125:386-391

10. Hussain LA, Lehner T (1995) Comparative investigation of Langerhans' cells and potential receptors for HIV in oral, genitourinary and rectal epithelia. Immunology 85:475-484

11. Patterson BK, Landay A, Siegel JN, Flener Z, Pessis D, Chaviano A et al (2002) Susceptibility to human immunodeficiency virus-1 infection of human foreskin and cervical tissue grown in explant culture. Am J Pathol 161:867-873

12. Szabo R, Short RV (2000) How does male circumcision protect against HIV infection? BMJ 320:1592-1594

13. Weiss HA, Thomas SL, Munabi SK, Hayes RJ (2006) Male circumcision and risk of syphilis, chancroid, and genital herpes: a systematic review and meta-analysis. Sex Transm Infect 82:101-109 (discussion 110)

14. Neidleman JA, Chen JC, Kohgadai N, Muller JA, Laustsen A, Thavachelvam K et al (2017) Mucosal stromal fibroblasts markedly enhance HIV infection of CD4+ T cells. PLoS Pathog 13:e1006163

15. Fink AJ (1986) A possible explanation for heterosexual male infection with AIDS. N Engl J Med 315:1167

16. Bongaarts J, Reining P, Way P, Conant F (1989) The relationship between male circumcision and HIV infection in African populations. AIDS 3:373-377

17. Caldwell JC, Caldwell P (1996) The African AIDS epidemic. Sci Am 274(62-63):66-68

18. Moses S, Bradley JE, Nagelkerke NJ, Ronald AR, Ndinya-Achola JO, Plummer FA (1990) Geographical patterns of male circumcision practices in Africa: association with HIV seroprevalence. Int J Epidemiol 19:693-697

19. Cameron DW, Simonsen JN, D'Costa $\amalg$, Ronald AR, Maitha GM, Gakinya MN et al (1989) Female to male transmission of human immunodeficiency virus type 1: risk factors for seroconversion in men. Lancet 2:403-407

20. Gray RH, Kiwanuka N, Quinn TC, Sewankambo NK, Serwadda D, Mangen FW et al (2000) Male circumcision and HIV acquisition and transmission: cohort studies in Rakai, Uganda. Rakai Project Team. AIDS 14:2371-2381

21. Lavreys L, Rakwar JP, Thompson ML, Jackson DJ, Mandaliya K, Chohan BH et al (1999) Effect of circumcision on incidence of human immunodeficiency virus type 1 and other sexually transmitted diseases: a prospective cohort study of trucking company employees in Kenya. J Infect Dis 180:330-336

22. Mehendale SM, Shepherd ME, Divekar AD, Gangakhedkar RR, Kamble SS, Menon PA et al (1996) Evidence for high prevalence and rapid transmission of HIV among individuals attending STD clinics in Pune, India. Indian J Med Res 104:327-335

23. Reynolds SJ, Shepherd ME, Risbud AR, Gangakhedkar RR, Brookmeyer RS, Divekar AD et al (2004) Male circumcision and risk of HIV-1 and other sexually transmitted infections in India. Lancet 363:1039-1040 
24. Telzak EE, Chiasson MA, Bevier PJ, Stoneburner RL, Castro KG, Jaffe HW (1993) HIV-1 seroconversion in patients with and without genital ulcer disease. A prospective study. Ann Intern Med 119:1181-1186

25. Weiss HA, Quigley MA, Hayes RJ (2000) Male circumcision and risk of HIV infection in sub-Saharan Africa: a systematic review and meta-analysis. AIDS 14:2361-2370

26. Quinn TC, Wawer MJ, Sewankambo N, Serwadda D, Li C, WabwireMangen F et al (2000) Viral load and heterosexual transmission of human immunodeficiency virus type 1. Rakai Project Study Group. N Engl J Med 342:921-929

27. Wawer MJ, Gray RH, Sewankambo NK, Serwadda D, Li X, Laeyendecker O et al (2005) Rates of HIV-1 transmission per coital act, by stage of HIV-1 infection, in Rakai, Uganda. J Infect Dis 191:1403-1409

28. Siegfried N, Muller M, Volmink J, Deeks J, Egger M, Low N et al (2003) Male circumcision for prevention of heterosexual acquisition of HIV in men. Cochrane Database Syst Rev. https://doi.org/10.1002/14651858.CD003 362

29. Halperin DT, Bailey RC (1999) Male circumcision and HIV infection: 10 years and counting. Lancet 354:1813-1815

30. Lawoyin T, Kehinde OA (2006) Male circumcision and HIV in Africa. PLoS Med 3:e74 (author reply e67)

31. Garenne M (2006) Male circumcision and HIV control in Africa. PLoS Med 3:e78

32. Talbott JR (2007) Size matters: the number of prostitutes and the global HIV/AIDS pandemic. PLoS ONE 2:e543

33. Auvert B, Taljaard D, Lagarde E, Sobngwi-Tambekou J, Sitta R, Puren A (2005) Randomized, controlled intervention trial of male circumcision for reduction of HIV infection risk: the ANRS 1265 Trial. PLoS Med 2:e298

34. Bailey RC, Moses S, Parker CB, Agot K, Maclean I, Krieger JN et al (2007) Male circumcision for HIV prevention in young men in Kisumu, Kenya: a randomised controlled trial. Lancet 369:643-656

35. Gray RH, Kigozi G, Serwadda D, Makumbi F, Watya S, Nalugoda F et al (2007) Male circumcision for HIV prevention in men in Rakai, Uganda: a randomised trial. Lancet 369:657-666

36. Winkel R (2006) Rush to judgment. PLoS Med 3:e71 (author reply e67)

37. Wawer MJ, Makumbi F, Kigozi G, Serwadda D, Watya S, Nalugoda F et al (2009) Circumcision in HIV-infected men and its effect on HIV transmission to female partners in Rakai, Uganda: a randomised controlled trial. Lancet 374:229-237

38. Tobian AA, Kong X, Wawer MJ, Kigozi G, Gravitt PE, Serwadda D et al (2011) Circumcision of HIV-infected men and transmission of human papillomavirus to female partners: analyses of data from a randomised trial in Rakai, Uganda. Lancet Infect Dis 11:604-612

39. Wawer MJ, Tobian AA, Kigozi G, Kong X, Gravitt PE, Serwadda D et al (2011) Effect of circumcision of HIV-negative men on transmission of human papillomavirus to HIV-negative women: a randomised trial in Rakai, Uganda. Lancet 377:209-218

40. Fergusson DM, Boden JM, Horwood L (2006) Circumcision status and risk of sexually transmitted infection in young adult males: an analysis of a longitudinal birth cohort. Pediatrics 118:1971-1977

41. Kripke K, Njeuhmeli E, Samuelson J, Schnure M, Dalal S, Farley T et al (2016) Assessing progress, impact, and next steps in rolling out voluntary medical male circumcision for HIV prevention in 14 priority countries in eastern and southern Africa through 2014. PLoS ONE 11:e0158767

42. Kripke K, Njeuhmeli E, Samuelson J, Schnure M, Ncube B, Dalal S et al (2016) Correction: Assessing progress, impact, and next steps in rolling out voluntary medical male circumcision for HIV prevention in 14 priority countries in eastern and southern Africa through 2014. PLOS ONE 11:e0163757

43. Njeuhmeli E, Forsythe S, Reed J, Opuni M, Bollinger L, Heard N et al (2011) Voluntary medical male circumcision: modeling the impact and cost of expanding male circumcision for HIV prevention in eastern and southern Africa. PLoS Med 8:e1001132

44. Schoen EJ, Colby CJ, To TT (2006) Cost analysis of neonatal circumcision in a large health maintenance organization. J Urol 175:1111-1115

45. Kahn JG, Marseille E, Auvert B (2006) Cost-effectiveness of male circumcision for HIV prevention in a South African setting. PLoS Med 3:e517

46. Tchuenche M, Palmer E, Hate V, Thambinayagam A, Loykissoonlal D, Njeuhmeli E et al (2016) The cost of voluntary medical male circumcision in South Africa. PLoS ONE 11:e0160207
47. Kreiss JK, Hopkins SG (1993) The association between circumcision status and human immunodeficiency virus infection among homosexual men. J Infect Dis 168:1404-1408

48. Buchbinder SP, Vittinghoff E, Heagerty PJ, Celum CL, Seage GR III, Judson FN et al (2005) Sexual risk, nitrite inhalant use, and lack of circumcision associated with HIV seroconversion in men who have sex with men in the United States. J Acquir Immune Defic Syndr 39:82-89

49. Center for Diseases Control (2010) HIV/AIDS surveillance report: monitoring selected national HIV prevention and care objectives by using HIV surveillance data-United States and 6 US dependent areas-2010. http://www.cdc.gov/hiv/library/reports. Accessed 28 July 2017

50. Rice CE, Maierhofer C, Fields KS, Ervin M, Lanza ST, Turner AN (2016) Beyond anal sex: sexual practices of men who have sex with men and associations with HIV and other sexually transmitted infections. J Sex Med 13:374-382

51. Heynes CF, Krieger JN (eds) (2006) Andrology for the clinician. Springer, Berlin

52. Laumann EO, Masi CM, Zuckerman EW (1997) Circumcision in the United States. Prevalence, prophylactic effects, and sexual practice. JAMA 277:1052-1057

53. Lerman SE, Liao JC (2001) Neonatal circumcision. Pediatr Clin N Am 48:1539-1557

54. Rediger C, Muller AJ (2013) Parents' rationale for male circumcision. Can Fam Physician 59:e110-e115

55. Downs JA, Fuunay LD, Fuunay M, Mbago M, Mwakisole A, Peck RN et al (2013) 'The body we leave behind': a qualitative study of obstacles and opportunities for increasing uptake of male circumcision among Tanzanian Christians. BMJ Open 3:e002802

56. Lau FK, Jayakumar S, Sgaier SK (2015) Understanding the socio-economic and sexual behavioural correlates of male circumcision across eleven voluntary medical male circumcision priority countries in southeastern Africa. BMC Public Health 15:813

57. Peltzer K, Nqeketo A, Petros G, Kanta X (2008) Traditional circumcision during manhood initiation rituals in the Eastern Cape, South Africa: a pre-post intervention evaluation. BMC Public Health 8:64

58. Siegler AJ, Mbwambo JK, DiClemente RJ (2012) Acceptability of medical male circumcision and improved instrument sanitation among a traditionally circumcising group in East Africa. AIDS Behav 16:1846-1852

59. Westercamp N, Bailey RC (2007) Acceptability of male circumcision for prevention of HIV/AIDS in sub-Saharan Africa: a review. AIDS Behav 11:341-355

60. Sawires SR, Dworkin SL, Fiamma A, Peacock D, Szekeres G, Coates TJ (2007) Male circumcision and HIV/AIDS: challenges and opportunities. Lancet 369:708-713

61. Newell ML, Barnighausen T (2007) Male circumcision to cut HIV risk in the general population. Lancet 369:617-619

62. Benatar SR (1998) Imperialism, research ethics and global health. J Med Ethics 24:221-222

63. Modise M, Nhlatho M, Short R (2004) Stopping AIDS in Africa. Melb Univ Mag 21:3

64. Barone MA, Li PS, Awori QD, Lee R, Goldstein M (2014) Clinical trials using the Shang Ring device for male circumcision in Africa: a review. Transl Androl Urol 3:113-124

65. Kanyago S, Riding DM, Mutakooha E, de La Lopez OA, Siedner MJ (2013) Shang Ring versus forceps-guided adult male circumcision: a randomized, controlled effectiveness study in southwestern Uganda. J Acquir Immune Defic Syndr 64:130-133

66. Kigozi G, Musoke R, Watya S, Kighoma N, Ssebbowa P, Serwadda D et al (2013) The acceptability and safety of the Shang Ring for adult male circumcision in Rakai, Uganda. J Acquir Immune Defic Syndr 63:617-621

67. Lebina L, Taruberekera N, Milovanovic M, Hatzold K, Mhazo M, Nhlapo C et al (2015) Piloting PrePex for adult and adolescent male circumcision in South Africa_-pain is an issue. PLoS ONE 10:e0138755

68. Lee R, Osterberg EC, Li PS, Goldstein M, Barone M, Combes SL et al (2013) Proper surgical training and grading of complications for Shang Ring circumcision are necessary. J Acquir Immune Defic Syndr 64:e11

69. Ndagijimana A, Mugenzi P, Thomson DR, Hedt-Gauthier B, Condo JU, Ngoga E (2015) PrePex male circumcision: follow-up and outcomes during the first two years of implementation at the Rwanda Military Hospital. PLOS ONE 10:e0138287 
70. Weiss HA, Larke N, Halperin D, Schenker I (2010) Complications of circumcision in male neonates, infants and children: a systematic review. BMC Urol 10:2

71. Bailey RC, Egesah O, Rosenberg S (2008) Male circumcision for HIV prevention: a prospective study of complications in clinical and traditional settings in Bungoma, Kenya. Bull World Health Organ 86:669-677

72. Christakis DA, Harvey E, Zerr DM, Feudtner C, Wright JA, Connel FA (2000) A trade-off analysis of routine newborn circumcision. Pediatrics 105:246-249

73. Bailey RC, Muga R, Poulussen R, Abicht H (2002) The acceptability of male circumcision to reduce HIV infections in Nyanza Province, Kenya. AIDS Care 14:27-40

74. Lagarde E, Dirk T, Puren A, Reathe RT, Bertran A (2003) Acceptability of male circumcision as a tool for preventing HIV infection in a highly infected community in South Africa. AIDS 17:89-95

75. Mattson CL, Bailey RC, Muga R, Poulussen R, Onyango T (2005) Acceptability of male circumcision and predictors of circumcision preference among men and women in Nyanza Province, Kenya. AIDS Care 17:182-194
76. Ngalande RC, Levy J, Kapondo CP, Bailey RC (2006) Acceptability of male circumcision for prevention of HIV infection in Malawi. AIDS Behav 10:377-385

77. Payne K, Thaler L, Kukkonen T, Carrier S, Binik Y (2007) Sensation and sexual arousal in circumcised and uncircumcised men. J Sex Med 4:667-674

78. Rain-Taljaard RC, Lagarde E, Taljaard DJ, Campbell C, Macphail C, Williams B et al (2003) Potential for an intervention based on male circumcision in a South African town with high levels of HIV infection. AIDS Care 15:315-327

79. Sorrells ML, Snyder JL, Reiss MD, Eden C, Milos MF, Wilcox N et al (2007) Fine-touch pressure thresholds in the adult penis. BJU Int 99:864-869

80. Eaton L, Kalichman SC (2009) Behavioral aspects of male circumcision for the prevention of HIV infection. Curr HIV/AIDS Rep 6:187-193

\section{Publisher's Note}

Springer Nature remains neutral with regard to jurisdictional claims in published maps and institutional affiliations.

\section{Submit your manuscript to a SpringerOpen ${ }^{\circ}$ journal and benefit from:}

- Convenient online submission

- Rigorous peer review

- Open access: articles freely available online

- High visibility within the field

- Retaining the copyright to your article

Submit your next manuscript at $\boldsymbol{\nabla}$ springeropen.com 